\title{
THE BASIS OF LABOR EXEMPTIONS FROM THE ANTITRUST ACTS
}

IN the field of economic legislation a conflict of policy appears between the antitrust acts ${ }^{1}$ and the exemptions from them provided for labor unions by the Clayton ${ }^{2}$ and Norris-LaGuardia Acts. ${ }^{3}$ The general purpose of the antitrust acts, whatever disagreement there may be upon the details of their application, is to secure for the nation the advantages of a freely competitive economy, with commodity prices regulated by the market. The policy of the exempting acts, on the other hand, is to stimulate the growth of trade unions so as to equalize bargaining power between individual worliers and more powerful employers by permitting labor unions to obtain, if they can, a monopoly of labor in any given field. The Norris-LaGuardia Act states the Congressional policy thus:

"Whereas under prevailing economic conditions ... the individual unorganized worker is commonly helpless to exercise actual liberty of contract ..., wherefore ... it is necessary that he have full freedom of association, self-organization, and designation of representatives of his own choosing, to negotiate the terms and conditions of his employment. ...."

This policy, although contrary to the general aim of free competition, is not irreconcilable with it; for just as the existence of natural monopolies ${ }^{6}$ does not decrease the desirability of competitive conditions in general, so the undesirability of competitive condition in the labor markets ${ }^{7}$ does not vitiate the purpose of antitrust acts. In practice, however, it becomes necessary to inquire whether it matters what these exceptional monopoly powers of labor unions are used for, and, if it does, whether they may be used to prevent interstate shipment of goods, to raise prices,-or to satisfy a private grudge.

1. 26 Stat. 209 (1890), 38 Stat. 730 (1914), 15 U.S. C. $\$ \S 1$ et seq. $\S \S 12$ cl seq. (1910).

2. 38 StaT. 738 (1914), 29 U. S. C. $\$ 52$ (1940), 38 StaT. 731 (1914), 15 U. S. C. \$117 (1940).

3. 47 STat. 70 (1932), 29 U. S. C. $\S 101$ (1940).

4. For a general discussion of the purposes of the antitrust laws ege HodGEs, AritI-

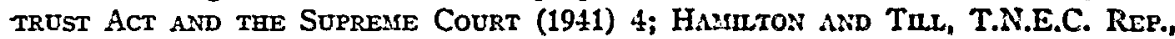
Antitrust in Action, Monograph 16 (1941) 5; Clars, Tae Federal Trust Policy (1931) cc. 3, 5; Thornton, Combinations in Restrintt of Trade (1928) ce. 1, 2; Walrese, History of the Shersian Law (1910) 13; Spelling, Trusts ando Mo:ogoltes (1693) c. 13.

5. 47 Stat. 70 (1932), 29 U. S. C. $\S 102(1940)$.

6. For an account of the extent to which such natural monopolies as railroads may ba subject to prosecution under the antitrust acts see H.LNDLER, TNEC RER., A SrEDr Of rII Construction and ENForcenent of the Federal ANti-trust Laws, Monograph 38 (1941) 57-9.

7. Arguments regarding the propriety of labor market monopolies tend to point, on one side, to the waste and injustice caused by union practices which tend to reduce employment and delay technological advance, and on the other to the more or less monopolistic 
The statutes, like their underlying policies, contain some contradiction, at least on their face. Section 6 of the Clayton Act ${ }^{8}$ purports only to exempt unions lawfully carrying out their legitimate objectives, while Section 20 can be interpreted to legalize, regardless of purpose, most of the usual tactical weapons of unions. ${ }^{9}$ It is not surprising, therefore, that the Supreme

position of many employers, even where their product market is competitive, and to tho hardship caused by a rapid technological change. See Shulman, Labor and the Anti-Trust Acts (1940) 34 Irr. L. REv. 769. Some economists doubt the desirability of labor monopolies by trade unions, and their compatibility with a free system in other respects. See Simons, A Positive Program for Laissez-Faire (1934). Certainly they reduce employment by volume where they are effective in raising wages. See Pigov, Principals and METIODS of Industrial Peace (1905) app. B; Dunlop and Higgins, "Bargaining Power" and Market Structures (1942) 50 J. PoL. ECoN. 1, 19, fig. 3.

8. Section 6 reads: "That the labor of a human being is not a commodity or article of commerce. Nothing contained in the antitrust laws shall be construed to forbid the existence and operation of labor, agricultural, or horticultural organizations, instituted for the purposes of mutual help, and not having capital stock or conducted for profit, or to forbid or restrain individual members of such organizations from lawfully carrying out the legitimate object thereof; nor shall such organizations, or the members thereof, be held or construed to be illegal combinations or conspiracies in restraint of trade, under the antitrust laws." 38 STAT. 731 (1914), 15 U. S. C. $\$ 17$ (1940).

9. Section 20 of the Clayton Act reads as follows: "That no restraining order or in. junction shall be granted by any court of the United States, or a judge or the judges thercof, in any case between an employer and employees, or between employers and employees, or between employees, or between persons employed and persons seeking employnent, involving, or growing out of, a dispute concerning terms or conditions of employment, unless necessary to prevent irreparable injury to property, or to a property right, of the party making the application, for which injury there is no adequate remedy at law, and such property or property right must be described with particularity in the application, which must be in writing and sworn to by the applicant or by his agent or attorney.

"And no such restraining order or injunction shall prohibit any person or persons, whether singly or in concert, from terminating any relation of employment, or from ceasing to perform any work or labor, or from recommending, advising, or persuading others by peaceful means so to do; or from attending at any place where any such person or persons may lawfully be, for the purpose of peacefully obtaining or communicating information, or from peacefully persuading any person to work or abstain from working; or from ceasing to patronize or to employ any party to such dispute, or from recommending, advising, or persuading others by peaceful and lawful means so to do; or from paying or giving to, or withholding from, any person engaged in such dispute, any strike benefits or other moneys or things of value; or from peaceably assembling in a lawful manner, and for lawful purposes; or from doing any act or thing which might lawfully be done in the absence of such disputc by any party thereto; nor shall any of the acts specified in this paragraph be considered or "held to be violations of any law of the United States." 38 SraT. 738 (1914), 29 U. S. C. $\$ 52$ (1940).

It has been held in United States v. Hutcheson, 312 U. S. 219, 231 (1941), that this act must be read with the Norris-LaGuardia Act which further narrowed the circumstances in which federal chancellors might grant injunctions in labor disputes, so that the activity therein described could be brought within the phrase "nor shall any of the acts specified in this paragraph be considered or held to be violations of any law of the United States." For an excellent criticism of this process of statutory importation see Steffen, Labor Activilics in Restraint of Trade: The Hutcheson Case (1941) 36 ILL. L. REv. 1, and Mr. Justice Roberts, dissenting in United States v. Hutcheson, 312 U. S. 219, 245 (1941). 
Court in construing these statutes ${ }^{10}$ has displayed some confusion, and has suggested in the last five years differing criteria governing labor's exemption from the acts. In Apex Hosiery Company a. Lcader, ${ }^{11}$ decided in 1940, the Court refused to apply the penalties of the Sherman Act to a trade union engaging in a sit-down strike which was attended by much violence and caused a considerable stoppage in interstate commerce. The doctrinal motif of the decision is revealed in the statement that the restraints of trade caused by the defendant union did not involve any "actual or intended effect on price or price competition." 12 "The Sherman Act," the Court continued, "was not enacted to police interstate transportation, or to afford a remedy for wrongs, which are actionable under state law, and result from combinations and conspiracies which fall short, both in their purpose and effect, of any form of market control of a commodity. . . ." 13 But this decision left some doubt as to what the Court would do where an actual or intended "effect on price," or "market control of a commodity" was revealed. ${ }^{14}$

By 1941, however, the question of effect on price appears to have lost its importance. In United States a. Hutcheson, ${ }^{15}$ a criminal proceeding in which it was sought to convict a union leader for picketing and secondary boycott in connection with a purely "jurisdictional" dispute, the purpose of which was to exclude another union from a certain type of employment, the Cuurt did not mention any effect on price but emphasized the labor exemptions of the Clayton Act to show that the defendant could not be convicted. "So long as a union," the Court said, "acts in its self-interest and does not combine with non-labor groups, ${ }^{16}$ the licit and illicit under Section 20 lof the Clayton Act] are not to be distinguished by any judgment regarding the wisdom or unwisdom, the rightness or wrongness, the selfishness or unselfishness of the end of which the particular union activities are the means." 17

The meaning of "self-interest of a union" was not made explicit; whether they might only seek ends which unions are traditionally supposed to seek,

10. For the previous history of the statutes see Steffen, Lalor Adtrilics in Reslraint of

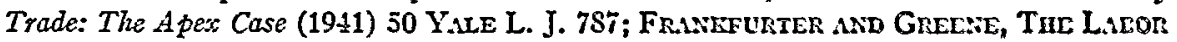
Injoncrion (1930); Magruder, A Half Century of Legal Intlucise C'pon the Declopmont of Collectire Bargaining (1937) 50 Harv. L. Rev. 1071; Comment (1940) 49 YaLL L. J. 518.

11. 310 U. S. 469 (1940).

12. Id. at 50 ?.

13. Id. at 512 .

14. There seems little doubt that the effect on price criterion was a general one, extending to labor and non-labor organizations alike. In reply to the objection of Hughes, C. J., that it seemed anomalous to hold employers liable for stoppages in commerce and not employees, Mr. Justice Stone, who delivered the opinion of the Court, stated: ".. . . it esems obvious that the Sherman Act cannot be said to subject employees to liability which it dors not impose on employers or others." Id. at 513, n. 28.

15. 312 U. S. 219 (1911).

16. The prohibition of combination with employers seems to originate in United States v. Brims, 272 U. S. $5 \frac{19}{\text { (1926). }}$

17. 312 U. S. 219,232 (1941). 
or whether they might seek any ends at all without violating the antitrust acts could not at the time be certain. Last term in Hunt v. Crumboch 18 it became apparent that the latter was the intent of the Court. ${ }^{19}$ The defendant union, the Teamsters of Philadelphia, had a grudge against the Hunt brothers, who were doing business as an interstate trucking partnership, because they believed one of them to be guilty of the murder of a union member, a crime of which he had been acquitted. By intimidation of the customers of the partnership and by refusing to allow their members to work for it under any conditions or to admit its employees as members, the teamsters forced Hunt Brothers out of business. The trial court and the circuit court of appeals found for the union ${ }^{20}$ on the authority of the $A p E x$ case because the restraint of trade did not affect price or price competition. The Supreme Court, however, affirmed on a different ground. Congress, the Court said, had manifested no intention "to make any kind of refusal to accept personal employment a violation of the Anti-trust laws." 2.1 Although the Apex case was cited as authority for this holding, the Court's statement that the defendants' activity, if carried on by a business competitor, would have been a violation of the Sherman Act seems to indicate a final abandonment of "effect on price" as a limiting criterion, for under the Apex doctrine neither business nor labor organizations could be convicted without actual or intended effect on price. ${ }^{22}$

If the "self-interest" of a union announced in the Hutcheson case is to be interpreted to include all possible aims, the qualifying prohibition of "combination with non-labor groups" is open only to the narrowest construction. From Allen Bradley Company v. Local Union No. $3{ }^{23}$ decided the same day as the Hunt case, it appears that proof of an actual conspiracy between two or more employers and a union is necessary to bring union activity within

18. 65 Sup. Ct. 1545 (U. S. 1945).

19. But this interpretation does not coincide with the views of the author of the Hutcheson opinion, Mr. Justice Frankfurter, who dissented in the Hunt case, stating that the exempting acts extended only to legitimate dues of trade unions. See note 28 infra.

20. $143 \mathrm{~F}$. (2d) 902, 903 (C.C.A. 3d, 1944); aff'g Hunt v. Brotherhood of Transportation Workers, Local 107, 47 F. Supp. 571, 573 (E. D. Pa. 1942).

21. 65 Sup. Ct. 1545,1547 (U. S. 1945).

22. See note 13 supra. Despite the abandonment of the doctrine of the $A$ pex case the general dictum found in it that the Sherman Act should not be construed to upset the "proper distribution between state and national governments of police authority and of remedies private and public for private wrongs" was used to support the decision in the Hunt case. The court hints that the plaintiffs had mistaken their remedy, and should have started in a state court, presumably in an action on the case. Such a procedure, however, would appear to disturb the previously existing balance between state and federal remedial powers more than a reverse one since such an action could previously have been maintained under the Sherman Act. Quaere whether the Supreme Court's view is consistent with the tendency recently displayed to limit state regulation of labor unions. See Hill v. Florida, 65 Sup. Ct. 1373 (U. S. 1945), Alabama State Federation of Labor v. McAdory, 65 Sup. Ct. 1384 (U. S. 1945); C. I. O. v. McAdory, 65 Sup. Ct. 1395 (U. S. 1945).

23. 65 Sup. Ct. 1533 (U. S. 1945). 
the scope of the antitrust laws. ${ }^{24}$ Here the union, by means of multilateral contracts with employers in both the manufacturing and installation branches of the electrical industry in New York City, had obtained for the three groups a monopolistic position of great power in that area. The Court held that, if they had achieved the same result by a bare refusal to work upon goods not made by their members, they would not have been violating the Sherman Act, and modified the trial judge's injunction accordingly..$^{23}$

Thus the Supreme Court seems to have decided that all labor activities should be exempt from the antitrust acts unless a combination or conspiracy with employers can be proved. In doing so, despite its recent assertion to the contrary, ${ }^{26}$ it has rejected the opportunity to achieve a meaningful reconciliation between labor combinations and free enterprise in other fields, and has, in effect, instructed labor that it may, if it acts alone, create any monopolies that may appear advantageous to its leaders. ${ }^{77}$ While it is true that the Court might have adopted the more realistic view of the minority that the statutory exemption for labor unions was "intended only to shield the legitimate objectives of such organizations," =3 even this criterion would not avoid the difficulty of evaluating labor aims in terms of economic policy.

24. Mr. Justice Roberts, concurring in the Allerz Bradley case, evaluated the Court's holding thus: "As I understand the opinion of the court, such a programme . . . Ithe exclusion from New York City of articles manufactured elsewhere] is wholly within the law: provided only that employers do not jointly agree to comply with the union's demands. . . . The union is at liberty to impose every term and condition as shown by the record in this case and to enforce those conditions and procure an agreement from each employer to such conditions by calling strikes, by lockout, and boycott, provided only such employer agrees for himself alone and not in concert with any other." Id. at 1542-3.

25. Black, J., who delivered the opinion of the Court, states: ". . . When ve turn to the sweeping commands of the injunction, we find that its terms . . . restrained the union, even though not acting in concert with the manufacturers, from doing the very things that the Clayton Act specifically permits unions to do. We agree with the following statement of the Circuit Court of Appeals:

"[The mandate of the injunction] might well have been stated . . . as restraining Local 3 and its officers "from terminating any relation of employment." " " Id. at 1541.

26. ". . . we have two declared congressional policies which it is our responsibility to try to reconcile." Id. at 1538.

27. There seems little doubt that unions will take advantage of this grant of judicial immunity, indeed they have not waited for it, and the court reports alone bare witness to the scope of their activities in restraint of trade. See, e.g., Lumber Products Ass'n v. ''nited States, 144 F. (2d) 546 (C. C. A. 9th, 1941); United States v. International Longehoremen's Ass'n, S. D. N. Y. No. 106-448, 1940 (dismissed after the decision in the Huteleson cass); Lake Valley Farm Products, Inc. v. Milk Wagon Drivers' Union, Local 753, 103 F. (2d) 436 (C. C. A. 7th, 1939); Local 167, International Brotherhood of Teamsters v. United States, 291 U. S. 293 (1931); United States v. Brims, 272 U. S. 549 (1926).

28. 65 Sup. Ct. 1549 (U. S. 1945). Professor Shulman in 1940, urging greater exemption for labor unions under the antitrust acts, stated that restraints by labor are not violations if the controversy "(a) is between 'employers and employees, or between employces' and (b) involves or grows out of a "dispute concerning terms or conditions of employment." " Shulman, Labor and the Anti-Trust Laws (1940) 34 ILL. L. Rev. 769, 781. This description would hardly embrace the exemption accorded the union in the Hust case. 
Since the Congressional policy in limiting the application of the antitrust acts is to equalize the bargaining power of worker and employer, ${ }^{29}$ a proper solution of the problem requires an examination of the bargaining position of each group in different situations. ${ }^{30}$ In the hypothetical case of a purely competitive economy neither employers nor employees would have any bargaining advantage, but in any existing economy where the degree of competition varies between one market and the other it is necessary, in order to evaluate the effect of bargaining power in the labor market, not merely to ascertain the relative numbers of buyers (employers) and sellers (employees) in that field but also to distinguish between various more or less competitive situations in the market for its product. ${ }^{31}$ When monopolistic conditions prevail in a product market restrictions in production will reduce the demand for labor, because under conditions of less than perfect competition restriction on production, by increasing price more than cost, is profitable to the producer. Moreover, such a monopoly frequently gives the employer monopsony power in the labor market which improves his relative position. Thus the bargaining power of labor as between itself and its employers is greatest, as measured by wages, when the supply of labor is monopolized-as by a powerful trade union-and conditions most nearly approaching free competition prevail in the product market. ${ }^{32}$ However, despite their less favorable position relative to employers resulting from monopoly in the product market, unions frequently find it advantageous to aid in the creation of such monopolies in return for a share of the resulting profits. ${ }^{33}$

29. See note 4 supra.

30. Bargaining power is measured by the ability of each contracting party to influence the wage paid to labor. The bargaining advantage, positive or negative, will equal the actual price paid the labor factor less the supply price which would prevail in pure competition over the demand price which would prevail in the competitive economy, where the bargaining advantage would be zero. Thus bargaining advantage of labor equals $\frac{\mathrm{Pf}-\mathrm{Scp}}{\mathrm{Dcp}}$ (when Pf equals actual price paid, Scp equals competitive supply price and Dep equals competitive demand price). See Dunlop and Higgins, "Bargaining Power" and Marliet Structures (1942) 50 J. PoL. Econ. 1.

31. The demand curve of the entrepreneur will vary according to the degree of competition prevailing in the product market, and the supply curve of the workers varies according to the degree in which monopoly prevails in the labor market. For a table in which the bargaining power of labor is arranged in order of magnitude in different situations see Dunlop and Higgins, supra note 30 , at 19.

32. See note 26 supra.

33. The failure to distinguish between situations where unions are getting profits from a monopoly in the product market and where they must depend on their bargaining power in the labor market alone probably accounts for contradictory statements as to the relative benefits to labor of "competitive" and "monopolistic" industries. See, e.g., DavGHertr, Labor Problems in American Industry (5th ed. 1941) 305; Blum, Labor Economics (1925) 375. In the absence of monopoly profits from the product market, a monopolistic union appears to have an advantage in the labor market when the market in which employers must sell is competitive. 
If labor exemption is to be reconciled with the antitrust acts, it should include only activities which tend to improve the bargaining position of employees with relation to their employers. Interferences in the product market cannot be justified, ${ }^{34}$ since their effect is not to gain bargaining advantage with employers but to obtain superiority for both groups over the consumer-the very situation which the antitrust acts forbid. Thus the defendants in the $A$ pex case ${ }^{35}$ were properly successful, since the only aim of the union was to improve its position with relation to the employers, and it made no attempt at market control. In the Hutcheson case, ${ }^{23}$ despite the jurisdictional aspects of the dispute, the union's activity was intended to affect only the labor market, and may also be regarded as within the scope of the exempting acts. ${ }^{37}$ The activities in the Hunt case, ${ }^{33}$ however, cannot be justified. It is true that they were not aimed at control of the product market, but neither did they tend to improve the position of the union in its proper sphere. ${ }^{39}$ Thus they fall without the purpose of the exempting acts.

The $A$ pex: case, in so far as it set up market control as a criterion limiting labor's exemption from the acts, pointed generally to a realistic approach to the problem. However, the doctrine of "effect on price" announced in that case as a test of market control appears erroneous, since it fails to distinguish between product and factor markets, as price would presumubly be affected both by legitimate labor activities in the labor market, and by unjustified restraints in the product market. ${ }^{\text {ij }}$

34. Only interference of a sort which would be unlawful for non-lat or organizations is intended. Semi-restrictive activities, such as advertising and afixing "union-made" latals to goods would not in any event appear to be in violation of the antitrust laws.

35. 310 U. S. 469 (19:40).

36. 312 U. S. 219 (1941).

37. But see Steffen, Labor Actizilies in Restraint of Trade: The Hutheson Cuse (1941) 36 ILL. L. REv. 1. It may be doubted whether, as a matter of social policy, the juriedictional strike is a permissible weapon since the enactment of the National Lator Relations Act. It would seem preferable, however, to deal with such inter-labor difficulties by mcans of $\mathrm{kg}_{\mathrm{g}} \mathrm{isl}$ tion other than the Sherman Act. For an account of the nature and estent of juric lictional trade disputes see Galenson, Rrval Unionssin in the United States (1910).

38. 65 Sup. Ct. 1545 (U. S. 1945).

39. Legislative mandate for distinguishing batween legitimate and other labor activities is contained in Section 6 of the Clayton Act. See note S supro.

40. Since it has the effect of raising variable costs, a rise in the price of labor-as causad by monopoly in the labor market alone-should be reflected on price inmcdiately. But soe Yoder, The Structure of the Denand for Labor (1942) 32 Ass. Econ. Rev. Supp. 261. For a criticism of the Apes price-effect doctrine see Steffen, Labor Aclitilies in: Restraint of Trode. The Apex Case (1941) 50 YALE L. J. 787. 